\title{
Mortality of kiwifruit pests (Coccoidea) exposed to ethyl formate delivered using either carbon dioxide or nitrogen carrier gases
}

\author{
Samuel D.J. Brown*, Natalie E.M. Page-Weir, Amanda J. Hawthorne, Reuben T. \\ Wilkinson, Lisa E. Jamieson, Dominic E. Hartnett, Simon P. Redpath, Asha Chhagan \\ The New Zealand Institute for Plant \& Food Research Limited (PFR), PO Box 92169, Mt \\ Albert, Auckland, New Zealand \\ *Corresponding author: Samuel.Brown@plantandfood.co.nz
}

\begin{abstract}
Ethyl formate (EF) is used as a fumigant against insect pests on many commodities. Delivery of EF uses a carrier gas, usually carbon dioxide $\left(\mathrm{CO}_{2}\right)$, to reduce its flammability. However, $\mathrm{CO}_{2}$ is expensive and can only be delivered relatively slowly. Nitrogen $\left(\mathrm{N}_{2}\right)$ has been proposed as an alternative. The efficacy of EF delivered using $\mathrm{CO}_{2}$ or $\mathrm{N}_{2}$, was evaluated at 5 and $15^{\circ} \mathrm{C}$, against two important postharvest pests of kiwifruit (greedy scale (Hemiberlesia rapax, Hemiptera: Diaspididae) and obscure mealybug (Pseudococcus viburni, Hemiptera: Pseudococcidae)). Mortalities of both insect species were higher in the presence of $\mathrm{CO}_{2}$ than $\mathrm{N}_{2}$. There was a strong interaction with treatment temperature: $\mathrm{N}_{2}$ at $5^{\circ} \mathrm{C}$ resulted in low mortality across both species. Greedy scale was more susceptible to EF than obscure mealybug across all treatments. Nitrogen as a carrier gas for EF substantially lowered the efficacy of $\mathrm{EF}$ as an insecticidal fumigant, relative to $\mathrm{CO}_{2}$. This is hypothesised to be caused by differing respiration rates across temperatures and $\mathrm{CO}_{2}$ concentrations. Solutions for rapid $\mathrm{CO}_{2}$ delivery should be explored over further trials with $\mathrm{N}_{2}$ at low temperatures.
\end{abstract}

Keywords: fumigation, disinfestation, quarantine.

\section{INTRODUCTION}

Exports of New Zealand-grown fruit are a major contributor to the New Zealand economy. Insects found on fruit destined for export pose a quarantine risk which can result in fruit being rejected at the border. A number of risk reduction treatments are available including cold treatment targeting scale insects (Jamieson et al. 2009) and removal of mobile surface pests using brushing and/or high-pressure air or water (Woolf et al. 2015, 2017). Despite these alternatives, fumigation remains an important option for ensuring market access and methyl bromide has commonly been used as a fumigation option. However, methyl bromide is an ozone-depleting chemical and New Zealand has committed to seek and to use alternative fumigants as part of its obligations under the Montreal Protocol on Substances that Deplete the Ozone Layer (UNEP 2000). Phosphine has been trialled as an alternative to methyl bromide to control scale and mealybugs on kiwifruit (Jamieson et al. 2012) but the protracted length of the phosphine treatment needed to control mites resulted in fruit-quality issues.

Ethyl formate (EF) is a volatile compound that occurs naturally in some plants. It is used as a food additive and flavouring agent, has low toxicity to humans and breaks down to formic acid and ethanol, leaving no residues (FDA 2017). Previous research has shown that a 0.3$1 \% \mathrm{EF}+$ carbon dioxide $\left(\mathrm{CO}_{2}\right)$ treatment applied at $15-20^{\circ} \mathrm{C}$ for $1 \mathrm{~h}$ was sufficient to kill $99 \%$ of susceptible pests such as thrips, scale insects and

New Zealand Plant Protection 71: 102-111 (2018)

https://doi.org/10.30843/nzpp.2018.71.152 
mealybugs, while more tolerant insects such as diapausing two-spotted mites and leafrollers required $\sim 2 \%$ EF for $2-3 \mathrm{~h}$ to achieve a $99 \%$ mortality rate (Simpson et al. 2007; Chhagan et al. 2013; Griffin et al. 2013).

Historically, fumigation trials testing $\mathrm{EF}$ have been conducted at $15^{\circ} \mathrm{C}$ or over, in accordance with manufacturers' instructions. Results from previous small-scale, semi-commercial and commercial trials have indicated that a temperature reduction from 15 to $5^{\circ} \mathrm{C}$ tended to increase the concentration of $\mathrm{EF}$ required to effectively control more tolerant pests, such as diapausing two-spotted spider mite and codling moth. However, a lower treatment temperature did not significantly reduce the efficacy of the same EF concentrations against susceptible pests (L.E. Jamieson unpublished data).

In New Zealand, EF is commercially available as VAPORMATE ${ }^{\mathrm{mm}}$ fumigant (16.7 weight $\% \mathrm{EF}$ in carbon dioxide; BOC 2016). A commercial trial using VAPORMATE applied in a tent containing 18 pallets of fruit with forced air circulation required nearly $3 \mathrm{~h}$ to reach the target of $2 \%$ $\mathrm{EF}$ in the headspace of the tent (L.E. Jamieson unpublished data). This time was considered too long for a commercial operation (Frank Bollen, Zespri Group Limited, personal communication). Researchers at Murdoch University in Western Australia working in collaboration with Chevron Corporation (Australia) have developed a commercial EF delivery system using nitrogen $\left(\mathrm{N}_{2}\right)$ as a carrier, allowing the vapour to be dispensed more quickly than in $\mathrm{CO}_{2}$ (M. Agrawal, Murdoch University, personal communication).

The aim of this research was to evaluate the efficacy of $\mathrm{EF}$ at two temperatures (5 and $15^{\circ} \mathrm{C}$ ), when delivered using either $\mathrm{CO}_{2}$ or $\mathrm{N}_{2}$ as a carrier gas. Two kiwifruit pests, greedy scale (Hemiberlesia rapax (Comstock, 1881), (Hemiptera: Diaspididae)) and obscure mealybug (Pseudococcus viburni Signoret, 1875, (Hemiptera: Pseudococcidae)), were used in these trials. Both pests can be controlled at EF concentrations that kiwifruit can tolerate without a decline in quality of the fruit (L.E. Jamieson unpublished data), although the current trial used potatoes as the insect host.

\section{MATERIALS AND METHODS \\ Insects}

Insects for treatment were obtained from colonies maintained at The New Zealand Institute for Plant and Food Research Limited (PFR), Auckland. Greedy scale had been maintained on 'Red Rascal' potatoes, while obscure mealybugs were reared on sprouting 'Agria' potatoes. Infested potatoes were collected from each colony and placed into plastic containers $(100 \mathrm{~mm}$ high $\times 85 \mathrm{~mm}$ diameter at base, $105 \mathrm{~mm}$ diameter at top) with fine metal mesh $(0.085 \mathrm{~mm}$ aperture, 200 squares per inch) inserted into lids and bases. Each container contained a single potato of the same cultivar used to rear the insects. On this potato was a mixture of life stages, with approximately 100 individuals of each life stage (first-, secondand third-instar nymphs for greedy scale; first-, second-, and third-instar nymphs and adults for obscure mealybug) prior to treatment. Pretreatment counts were not undertaken.

\section{Treatments}

Insects were exposed to 1-hour treatments of either $\mathrm{EF}+\mathrm{CO}_{2}$ or $\mathrm{EF}+\mathrm{N}_{2}$ in the Volatile Treatment Facility (VTF) at PFR, Auckland. This facility consists of 28 stainless steel, gas-tight chambers (sealed, 76.8 L capacity) housed within a controlled temperature room. A customwritten LabVIEW computer program controlled the amount of EF and $\mathrm{CO}_{2}$ or $\mathrm{N}_{2}$ delivered to each chamber. The $\mathrm{CO}_{2}$ or $\mathrm{N}_{2}$ flow rate increased with increasing EF concentration, to simulate the application of VAPORMATE fumigant (16.7 weight $\% \mathrm{EF}$ in $\mathrm{CO}_{2}$ ). The carrier gas stream $(10 \mathrm{~L} / \mathrm{min})$ was passed through a heated bead bath $\left(75^{\circ} \mathrm{C}\right)$, beforeliquid EF (Merck, $98 \%$ ) was injected using a micro-dispenser (INKX0523050A, The Lee Company, Westbrook CR, USA) into the heated gas stream. The combined mixture was passed through the heated bead bath to volatilise the EF, resulting in a final gas mixture which was delivered to each respective chamber. Each of the treatment chambers contained a $75-\mathrm{mm}$ diameter axial-flow fan attached to the ceiling to 
ensure a homogenous atmosphere was generated and maintained within each sealed chamber.

The chambers were filled automatically one after the other with the specified $\mathrm{EF}\left(+\mathrm{CO}_{2}\right.$ or $\mathrm{N}_{2}$ ) mixture. Treatments were conducted at a pressure of 1 atmosphere $(101 \mathrm{kPa})$. Throughout each treatment, gas samples were taken and analysed using a Shimadzu GC2014 gas chromatograph fitted with a $30 \mathrm{~m} \times 0.25 \mathrm{~mm}$ internal diameter $\times 0.25 \mu$ m packing depth fused silica (Stabilwax) column (Restek, Bellefonte, PA, USA) and a Shimadzu FID-2014 flame ionisation detector. Analyses to determine the amounts of EF, $\mathrm{CO}_{2}$ and oxygen $\left(\mathrm{O}_{2}\right)$ present in each chamber were conducted with a column temperature at a constant $90^{\circ} \mathrm{C}$ and used $\mathrm{N}_{2}$ as a carrier gas. Control samples using carrier gas only were placed in a VTF chamber and subjected to the highest concentration of the carrier gas, but without any EF mixed into the gas stream. Untreated (ambient atmosphere) control samples were placed at the back of the controlled temperature room in a wire basket. Three replicates of all treatments (5 or $6 \mathrm{EF}$ concentrations) plus controls (ambient and carrier gas controls) were carried out for each species.

After each specified treatment time, the chambers were purged with air for approximately $6 \mathrm{~min}$, after which the chambers were opened and samples removed and held in a controlled temperature room at $20^{\circ} \mathrm{C}$ with a $16: 8$ light:dark cycle until assessment.

\section{Insect mortality assessment}

Pest mortality was assessed 2 to 4 days (obscure mealybug) or 7 to 9 days (greedy scale) after treatment. Post-treatment reproduction and development were considered unlikely to bias mortality assessments, due to the long developmental periods of both species (Blank et al. 2000; da Silva et al. 2017). The later assessment time of greedy scale allowed more time for dead insects to dehydrate and thus make mortality assessment more reliable. Each infested potato was assessed under a stereo microscope $(5-40 \times$ magnification). For each sample, 100 individuals of each life stage were haphazardly selected for assessment of mortality.

Obscure mealybugs were assessed using blunt forceps to prod each insect gently. Mealybugs were assessed as live (active movement), dead (no movement when prodded), or moribund (slight movement of legs when prodded but no active movement).

Greedy scale were assessed by using a pin to lift off the scale test to reveal the insect body. Insects were assessed as live (full, turgid body of normal colour), dead (dried out body), or moribund (flaccid, partially dried and/or discoloured body).

\section{Statistical analyses}

Proportional mortality data were analysed using generalised linear mixed models using a binomial distribution and a logit link function. Models used, as predictor variables, the EF concentration and a categorical treatment group created from the concatenated values of life stage, carrier gas and temperature. Separate models were fitted for each species. Analyses were conducted in $\mathrm{R}$ computer language, using the packages lme4, optimx and qra.

\section{RESULTS}

The estimated lethal dose of EF required to kill $99 \%\left(\mathrm{LD}_{99}\right)$ of each insect life stage treated in this trial are presented in Tables 1 and 2 for greedy scale and obscure mealy bug respectively. The low mortality rates of insects at following $\mathrm{EF}+\mathrm{N}_{2}$ treatment at $5^{\circ} \mathrm{C}$ resulted in estimated $\mathrm{LD}_{99}$ values that are extremely high, reflecting the shallow slopes estimated by the models (e.g. Figs. $1 \& 2$, bottom left panels). Occasionally, higher mortality was observed at lower EF concentrations than at higher concentrations and negative $\mathrm{LD}_{99}$ values, biologically meaningless, were returned as a mathematical consequence of fitting the negative slope to the data: these have been reported in Tables 1 and 2 as NA.

Modelled greedy scale mortality was similar with either carrier gas when treated at $15^{\circ} \mathrm{C}$ (Fig. 1 , right panels). The first two life stages of greedy scale responded similarly to EF regardless of the carrier gas, as indicated by the overlapping 
Table 1 Estimated partial pressures of ethyl formate (\%) required for a 1-hour exposure to kill 99\% $\left(\mathrm{LD}_{99}\right)$ of greedy scale (Hemiberlesia rapax) when delivered using carbon dioxide $\left(\mathrm{CO}_{2}\right)$ or nitrogen $\left(\mathrm{N}_{2}\right)$ to various life stages.

\begin{tabular}{lllllll}
\hline Gas & $\begin{array}{l}\text { Temperature } \\
\left({ }^{\circ} \mathrm{C}\right)\end{array}$ & $\begin{array}{l}\text { Life stage } \\
\text { (instar) }\end{array}$ & $\mathrm{LD}_{99}$ & $\begin{array}{l}\text { Lower } \\
95 \% \mathrm{CI}\end{array}$ & $\begin{array}{l}\text { Upper } \\
95 \% \mathrm{CI}\end{array}$ & Variance \\
\hline $\mathrm{CO}_{2}$ & 5 & 1 & 0.78 & 0.72 & 0.85 & 0.00 \\
& 2 & 0.69 & 0.63 & 0.77 & 0.00 \\
& 3 & 0.76 & 0.72 & 0.82 & 0.00 \\
\cline { 2 - 7 } & 15 & 1 & 0.63 & 0.6 & 0.66 & 0.00 \\
& 2 & 0.67 & 0.63 & 0.73 & 0.00 \\
& & 3 & 0.63 & 0.6 & 0.67 & 0.00 \\
\hline $\mathrm{N}_{2}$ & 5 & 1 & $\mathrm{NA}$ & $\mathrm{NA}$ & $\mathrm{NA}$ & $\mathrm{NA}$ \\
& & 2 & 3.58 & 2.56 & 6.59 & 0.51 \\
& & 3 & 8.65 & 4.68 & 150.39 & 12.97 \\
& 15 & 1 & 0.68 & 0.64 & 0.72 & 0.00 \\
& & 2 & 0.68 & 0.63 & 0.75 & 0.00 \\
& & 3 & 0.88 & 0.83 & 0.94 & 0.00 \\
\hline
\end{tabular}

Footnote: NA indicates treatments where low mortality rates resulted in unrealistically high or negative $\mathrm{LD}_{99}$ estimates.

confidence intervals of estimated $\mathrm{LD}_{99}$ values (Table 1 , mean $\mathrm{LD}_{99}=0.66 \% \mathrm{EF}$ ). Third-instar insects, however, showed a slightly greater tolerance to $\mathrm{EF}$ when delivered with $\mathrm{N}_{2}\left(\mathrm{LD}_{99}=\right.$ $0.88 \% \mathrm{EF})$, than when delivered with $\mathrm{CO}_{2}\left(\mathrm{LD}_{99}\right.$ $=0.63 \% \mathrm{EF})$. When $\mathrm{CO}_{2}$ was used, $\mathrm{LD}_{99}$ values marginally increased for first and third instars when treatment occurred at $5^{\circ} \mathrm{C}\left(5^{\circ} \mathrm{C}\right.$ mean $\mathrm{LD}_{99}=0.77 \% \mathrm{EF} ; 15^{\circ} \mathrm{C}$ mean $\left.\mathrm{LD}_{99}=0.63 \% \mathrm{EF}\right)$, while second instar $\mathrm{LD}_{99}$ showed no significant difference across both temperatures $\mathrm{LD}_{99}=$ $0.68 \% \mathrm{EF})$. However, when $\mathrm{EF}$ was delivered with $\mathrm{N}_{2}$ at $5^{\circ} \mathrm{C}$, modelled mortality of all three life stages was substantially decreased (Fig. 1, bottom left panel), such that estimated $\mathrm{LD}_{99}$ values were unrealistically large, or negative and thus biologically meaningless.

The effect of $\mathrm{N}_{2}$ on obscure mealybug mortalities was even more pronounced. Regardless of treatment temperature or life stage, the use of $\mathrm{N}_{2}$ as the carrier gas markedly reduced mortality rates (Fig. 2). In contrast and contrary to expectations, $\mathrm{CO}_{2}$ treatments conducted at $5^{\circ} \mathrm{C}$ resulted in higher than expected mortality for adults and first- and third-instar mealybugs, such that $\mathrm{LD}_{99}$ estimates for these life stages were lower from $5^{\circ} \mathrm{C}$ treatments than $15^{\circ} \mathrm{C}$ treatments (Table 2). Second-instar mealybugs showed equally high mortality at both temperatures. In most cases, these high mortalities resulted in few informative data points being available for the model, resulting in high variance around $\mathrm{LD}_{99}$ estimates and inability to calculate confidence intervals around these estimates.

Target partial pressures of EF ranged from 0.2 to $1.2 \%$ (concentrations of 6 to $38 \mathrm{mg} / \mathrm{L}$ ), while measured partial pressures ranged from 0.18 to $1.18 \%$ (concentrations of 6 to $37 \mathrm{mg} / \mathrm{L}$ ). In the $\mathrm{EF}+\mathrm{CO}_{2}$ treatments, the partial pressure of $\mathrm{CO}_{2}$ ranged from 1.79 to $8.48 \%$. Some $\mathrm{CO}_{2}$ was produced by the fruit respiring, therefore, a mean partial pressure of $0.072 \% \mathrm{CO}_{2}$ (compared with $0.04 \% \mathrm{CO}_{2}$ at ambient) was measured in $\mathrm{EF}+$ $\mathrm{N}_{2}$ trials. Oxygen partial pressures ranged from 15.85 to $19.14 \%$ across all treatments (compared with $20.9 \%$ in ambient). 
Table 2 Estimated partial pressures of ethyl formate (\%) required for a 1-hour exposure to kill 99\% $\left(\mathrm{LD}_{99}\right)$ of obscure mealybug (Pseudococcus viburni) when delivered using carbon dioxide $\left(\mathrm{CO}_{2}\right)$ or nitrogen $\left(\mathrm{N}_{2}\right)$ to various life stages.

\begin{tabular}{|c|c|c|c|c|c|c|}
\hline Gas & $\begin{array}{l}\text { Temperature } \\
\left({ }^{\circ} \mathrm{C}\right)\end{array}$ & Life stage & $\mathrm{LD}_{99}$ & $\begin{array}{l}\text { Lower } \\
95 \% \text { CI }\end{array}$ & $\begin{array}{l}\text { Upper } \\
95 \% \text { CI }\end{array}$ & Variance \\
\hline \multirow[t]{8}{*}{$\mathrm{CO}_{2}$} & 5 & 1 & 0.25 & - & - & 0.40 \\
\hline & & 2 & 0.13 & - & - & 0.03 \\
\hline & & 3 & 0.14 & - & - & 0.03 \\
\hline & & Adult & 0.44 & 0.40 & 0.50 & 0.00 \\
\hline & 15 & 1 & 0.71 & 0.63 & 0.83 & 0.00 \\
\hline & & 2 & 0.11 & - & - & 0.10 \\
\hline & & 3 & 0.57 & 0.53 & 0.62 & 0.00 \\
\hline & & Adult & 0.68 & 0.64 & 0.75 & 0.00 \\
\hline \multirow[t]{8}{*}{$\overline{\mathrm{N}_{2}}$} & 5 & 1 & $\mathrm{NA}$ & $\mathrm{NA}$ & $\mathrm{NA}$ & NA \\
\hline & & 2 & NA & $\mathrm{NA}$ & NA & NA \\
\hline & & 3 & NA & NA & NA & NA \\
\hline & & Adult & NA & NA & NA & NA \\
\hline & 15 & 1 & 1.68 & 1.49 & 1.95 & 0.01 \\
\hline & & 2 & 2.31 & 2.05 & 2.67 & 0.02 \\
\hline & & 3 & 1.95 & 1.81 & 2.11 & 0.00 \\
\hline & & Adult & 2.15 & 2.00 & 2.35 & 0.01 \\
\hline
\end{tabular}

Footnote: NA indicates treatments where low mortality rates resulted in unrealistically high or negative $\mathrm{LD}_{99}$ estimates. Dashes (-) indicate treatments where high mortality rates prevented calculation of confidence intervals.

Interestingly, the two insect species differed in their susceptibility to the carrier gases, as indicated by the difference in mortality between the carrier gas and ambient atmosphere controls. Obscure mealybug had significantly higher mortality in the $\mathrm{CO}_{2}$ carrier gas controls (Table 3 ), while greedy scale had higher mortality in the $\mathrm{N}_{2}$ carrier gas controls (Table 3).

Overall, the use of $\mathrm{N}_{2}$ as a carrier gas greatly decreased the efficacy of $\mathrm{EF}$ as a fumigant compared with $\mathrm{CO}_{2}$. This was particularly evident at $5^{\circ} \mathrm{C}$ with incomplete mortality of all life stages of both insects found at even the highest EF concentrations when $\mathrm{N}_{2}$ was used as the carrier gas (Figs. 1 and 2, bottom left panels for greedy scale and obscure mealy bug respectively). This difference between carrier gases was especially noticeable in adult obscure mealybug, with very low actual and modelled mortalities across all concentrations of EF when delivered using $\mathrm{N}_{2}$ (Fig. 3).

\section{DISCUSSION}

The use of $\mathrm{N}_{2}$ as a carrier gas negatively affected the efficacy of EF in controlling obscure mealybugs and greedy scale, compared with $\mathrm{CO}_{2}$ as the carrier gas. This reduction in efficacy was especially noticeable in trials conducted at $5^{\circ} \mathrm{C}$, where the mortality responses of both greedy scale and obscure mealybug were significantly lower after exposure to $\mathrm{EF}+\mathrm{N}_{2}$ compared with $\mathrm{EF}+\mathrm{CO}_{2}$ across all concentrations of EF.

Previous trials by Jamieson et al. (unpublished data) where pests were treated with $\mathrm{EF}+\mathrm{CO}_{2}$ at 5,10 or $15^{\circ} \mathrm{C}$ showed that lower temperatures tended to increase the concentration of $\mathrm{EF}$ 


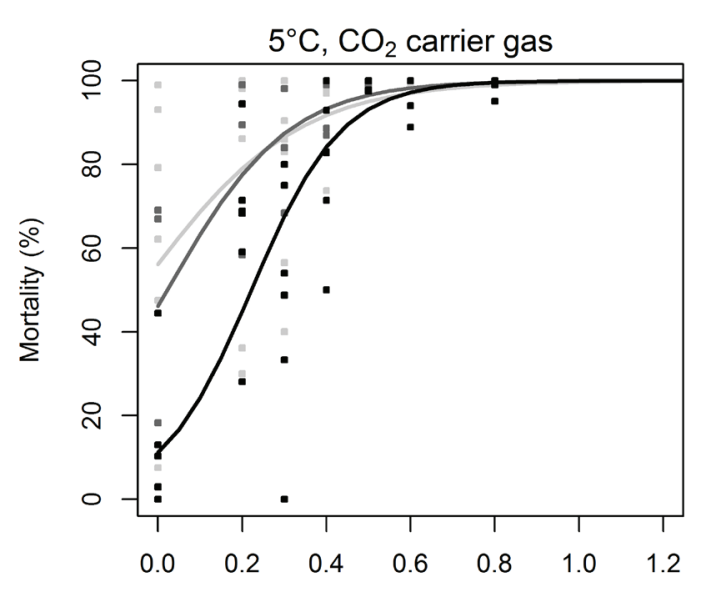

Ethyl formate partial pressure (\%)

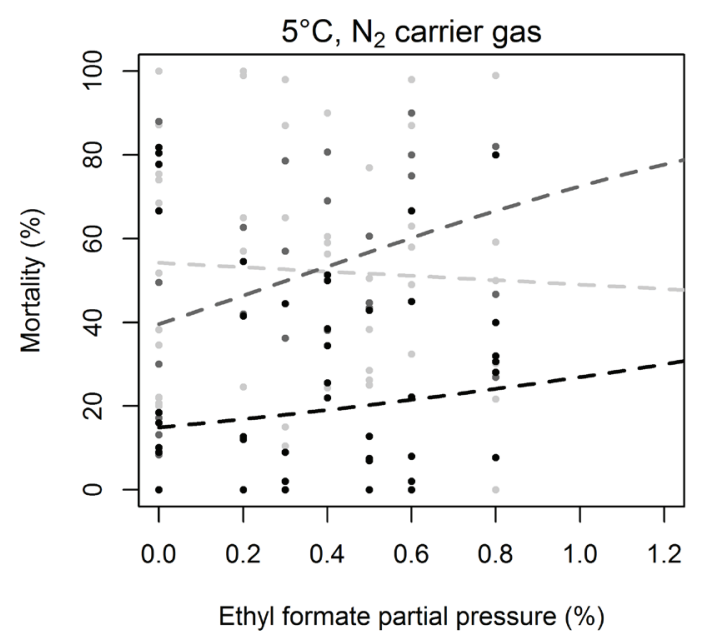

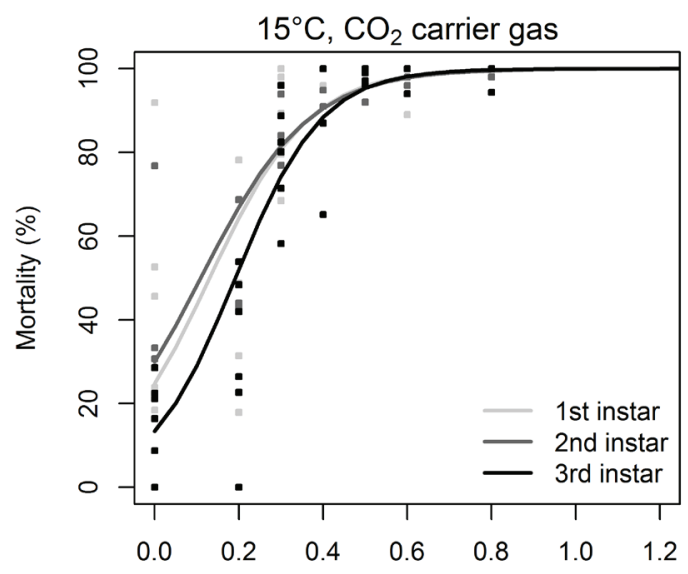

Ethyl formate partial pressure (\%)

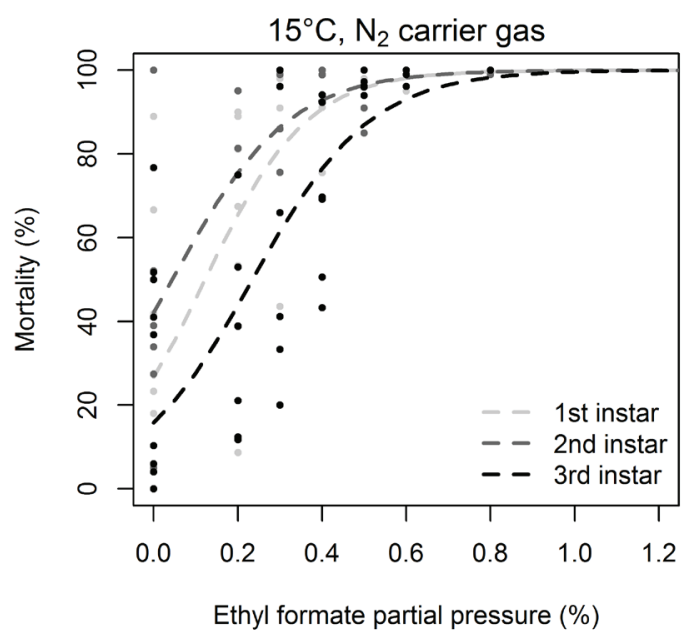

Figure 1 Actual (circles) and modelled (lines) mortality of each greedy scale (Hemiberlesia rapax) life stage after 1-hour exposure to ethyl formate applied with either nitrogen $\left(\mathrm{N}_{2}\right)$ or carbon dioxide $\left(\mathrm{CO}_{2}\right)$ as a carrier gas at either $5^{\circ} \mathrm{C}$ or $15^{\circ} \mathrm{C}$.

required for control of tolerant pests. However, treatment temperature had little effect on the concentration of $\mathrm{EF}$ required to control susceptible pests. Greedy scale and obscure mealybug (mobile life stages) are considered susceptible to EF (Griffin et al. 2013). Overall, the loss of EF efficacy against these pests was most noticeable after treatment with $\mathrm{EF}+\mathrm{N}_{2}$ when applied at the lower temperature of $5^{\circ} \mathrm{C}$; therefore, using EF with $\mathrm{N}_{2}$ as a carrier gas at $5^{\circ} \mathrm{C}$ is not recommended.

Although many studies have measured the toxicity of EF on various insect species (Vincent \& Lindgren 1972; Xin et al. 2008; Chhagan et al. 2013), there has been limited research on the mechanism of EF action. Dojchinov and Haritos 


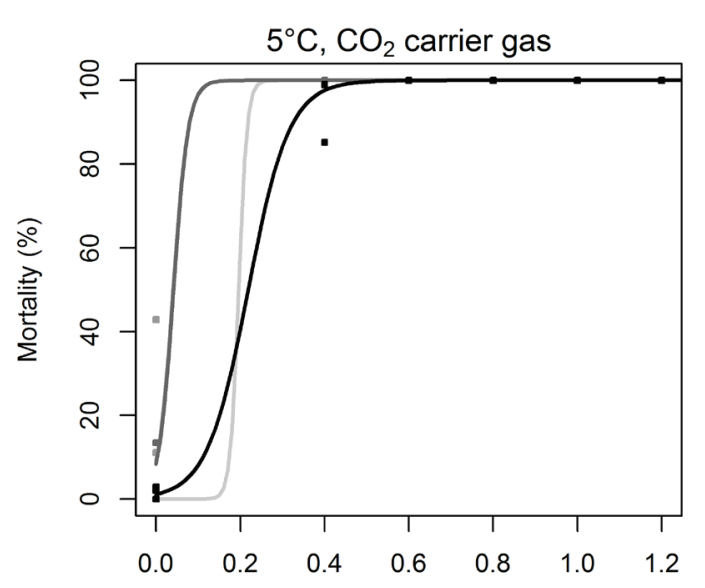

Ethyl formate partial pressure (\%)

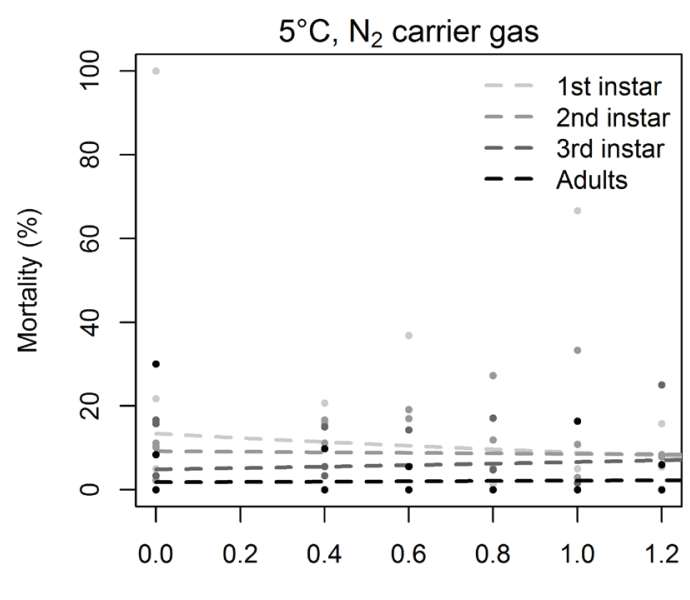

Ethyl formate partial pressure (\%)

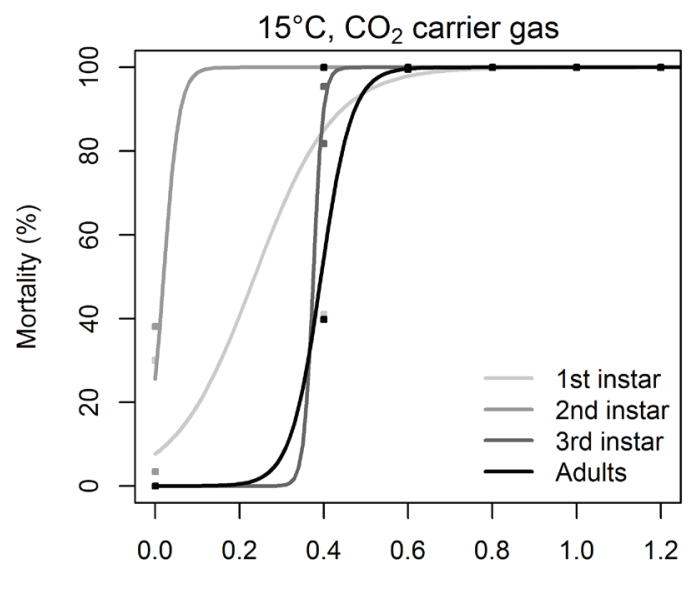

Ethyl formate partial pressure (\%)

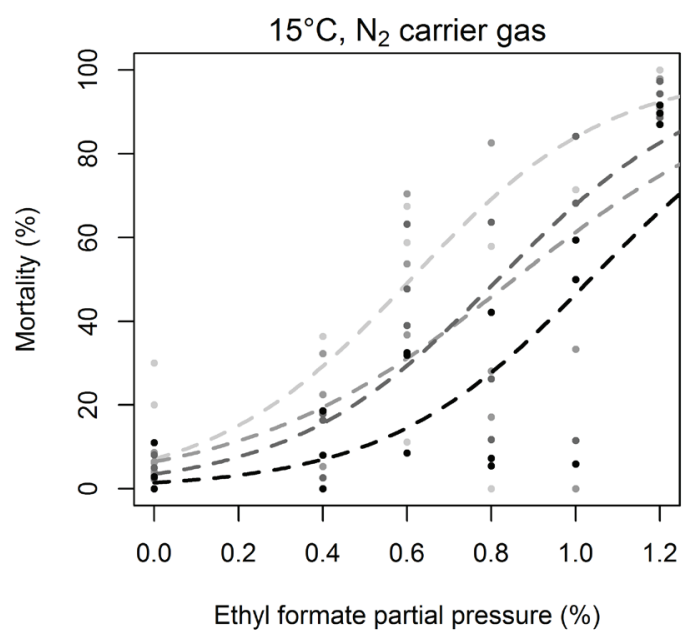

Figure 2 Actual (circles) and modelled (lines) mortality of each obscure mealybug (Pseudococcus viburni) life stage after 1-hour exposure to ethyl formate applied with either nitrogen $\left(\mathrm{N}_{2}\right)$ or carbon dioxide $\left(\mathrm{CO}_{2}\right)$ as a carrier gas at either $5^{\circ} \mathrm{C}$ or $15^{\circ} \mathrm{C}$.

(2003) found that some alkyl formates were rapidly metabolised by insect homogenates to produce high concentrations of formic acid and were of similar toxicity to pure formic acid. Formic acid itself inhibits the mitochondrial enzyme cytochrome oxidase (Liesivuori et al. 1991), which is part of the electron transport chain and is crucial for energy production within cells.
When $\mathrm{CO}_{2}$ is used as a carrier gas, the resulting atmosphere has $\mathrm{CO}_{2}$ partial pressures between $1 \%$ and $9 \%$, compared with an average of $0.07 \%$ in ambient conditions. At $\mathrm{CO}_{2}$ partial pressures over a critical threshold of $1-1.5 \%$, insects respond by opening their spiracles to maximise the rate of gas exchange (Förster \& Hetz 2010). In the context of these experiments, 
Table 3 Mean percent mortality of greedy scale (Hemiberlesia rapax) and obscure mealybug (Pseudococcus viburni) in carrier gas enriched (carbon dioxide $\left(\mathrm{CO}_{2}\right)$ and nitrogen $\left(\mathrm{N}_{2}\right)$ ) and ambient atmosphere controls. Mean $=$ mean mortality, $s=$ standard deviation, $t=t$-statistic, $\mathrm{df}=$ degrees of freedom, $d=$ Cohen's $d$ statistic of effect size, $\mathrm{P}=\mathrm{P}$ value.

\begin{tabular}{lllllllll}
\hline Species & Gas & Control & Mean & $s$ & $t$ & $\mathrm{df}$ & $D$ & $\mathrm{P}$ \\
\hline Greedy & $\mathrm{CO}_{2}$ & Carrier gas & 0.361 & 0.310 & 1.0053 & 56.27 & 0.260 & 0.319 \\
\cline { 3 - 8 } & & Ambient & 0.287 & 0.260 & & & & \\
\cline { 2 - 8 } & $\mathrm{N}_{2}$ & Carrier gas & 0.267 & 0.263 & -1.9817 & 53.32 & 0.515 & 0.053 \\
& & Ambient & 0.428 & 0.357 & & & & \\
\hline $\begin{array}{l}\text { Obscure } \\
\text { mealybug }\end{array}$ & $\mathrm{CO}_{2}$ & Carrier gas & 0.188 & 0.306 & 2.5371 & 32.75 & 0.666 & 0.016 \\
\cline { 2 - 8 } & & Ambient & 0.038 & 0.089 & & & & \\
\cline { 2 - 8 } & $\mathrm{N}_{2}$ & Carrier gas & 0.085 & 0.201 & 0.32649 & 41.079 & 0.085 & 0.746 \\
& & Ambient & 0.072 & 0.092 & & & & \\
\hline
\end{tabular}
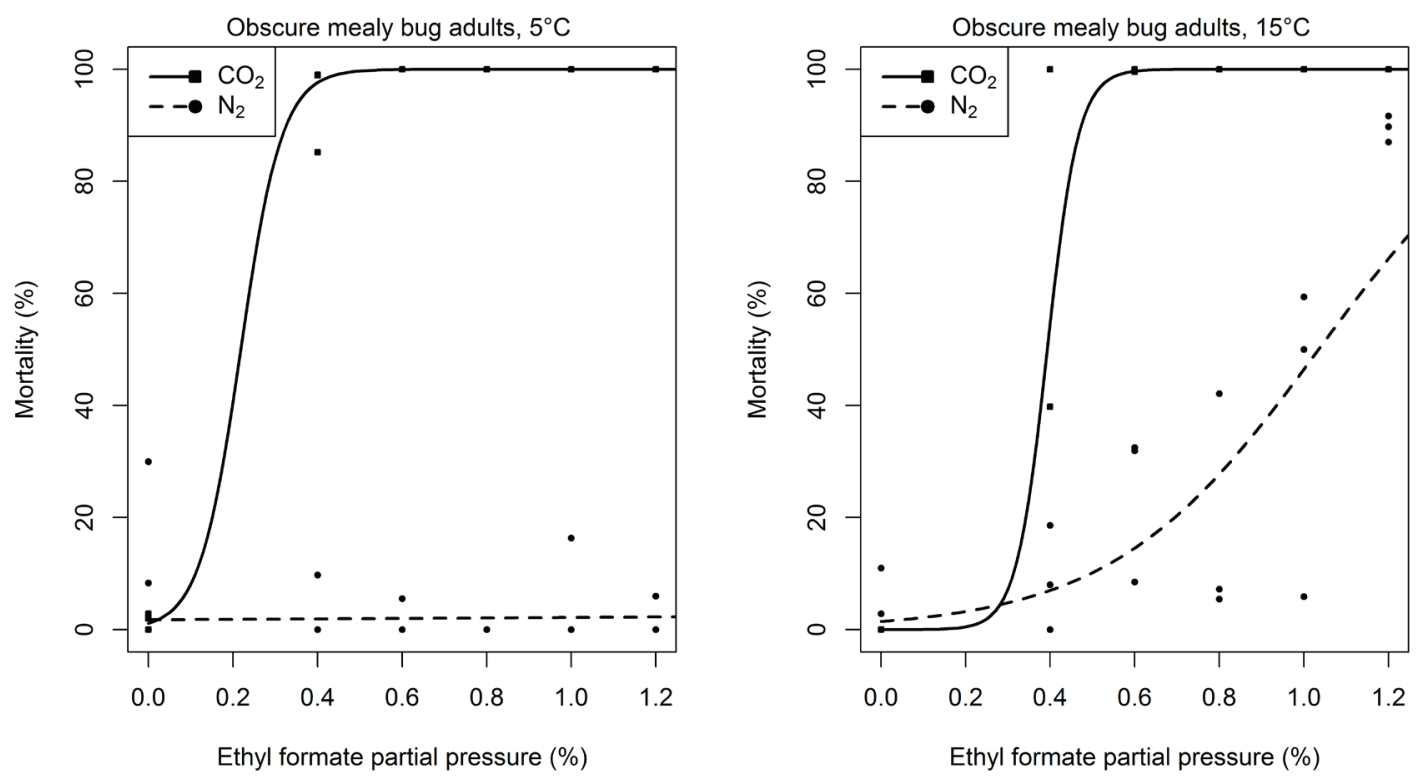

Figure 3 Actual (circles) and modelled (lines) mortality of adult obscure mealybug (Pseudococcus viburni) after 1-hour exposure to ethyl formate at 5 (left) and $15^{\circ} \mathrm{C}$ (right). Solid lines and square points represent carbon dioxide $\left(\mathrm{CO}_{2}\right)$ carrier gas, dashed lines and circular points represent nitrogen $\left(\mathrm{N}_{2}\right)$ carrier gas.

opening of spiracles due to the presence of $\mathrm{CO}_{2}$ would promote the uptake of $\mathrm{EF}$, resulting in higher mortality. Additionally, the rate of water loss increases when spiracles are open, with the result that insects at higher $\mathrm{CO}_{2}$ concentrations shift to metabolising stored fat to produce water to compensate for this loss (Damcevski et al. 1998). It is possible that $\mathrm{EF}$ is metabolised via the same fat metabolism pathways, accounting for the synergistic effects between $\mathrm{EF}$ and $\mathrm{CO}_{2}$ hinted at in this experiment and other research (Haritos et al. 2006). 
In comparison, the atmosphere resulting from delivery of EF using $\mathrm{N}_{2}$ is not appreciably different from ambient conditions. In particular, the average $\mathrm{CO}_{2}$ partial pressure of $0.072 \%$ is likely to result in the insects maintaining their normal cycles of spiracular activity (Förster \& Hetz 2010). This will limit the uptake of EF by the insects, particularly at low temperatures, as respiration rates of insects are strongly positively correlated with temperature (Lighton 1988; Heinrich \& Bradley 2014; Thienel et al. 2015). The lowered efficacy of EF delivered with $\mathrm{N}_{2}$ at $15^{\circ} \mathrm{C}$ observed in obscure mealybug compared with greedy scale (Figs. 1 \& 2, bottom right panel respectively), may indicate that obscure mealybug has a lower respiratory rate than greedy scale under normal conditions.

The idealised supply chain for kiwifruit is to retain the produce at a constant $0^{\circ} \mathrm{C}$ (Ritenour et al. 1999). Raising the fruit above this temperature results in a rapid decrease in fruit quality (Jeffery \& Banks 1994). Therefore, any fumigation treatment that seeks to maintain optimum fruit quality must provide acceptable control of insect pests at these low temperatures. The results obtained here indicate that EF is not an efficacious fumigant at low temperatures when $\mathrm{N}_{2}$ is used as a carrier gas. Therefore, alternative carrier gases and delivery systems need further investigation.

\section{ACKNOWLEDGEMENTS}

We wish to thank Bruce Freeth (PFR) for support with running the Volatile Treatment Facility and Kate Richards (PFR) for statistical advice. Funding for this project was received from Zespri Group Limited, under contract number MA1537 and Strategic Science Investment Funding (SSIF).

\section{REFERENCES}

Blank TH, Gill GSC, Kelly JM 2000. Development and mortality of greedy scale (Homoptera: Diaspididae) at constant temperatures. Environmental Entomology. 29(5): 934-942.

Chhagan A, Jamieson LE, Griffin MJ, PageWeir NEM, Poulton J, Zulhendri F, Feng R, Connolly PG, Davis VA, Olsson S, Redpath
SP, Kean AM, Woolf AB 2013. Postharvest management of New Zealand flower thrips (Thrips obscuratus) on apricots using ethyl formate or pyrethrum-based treatments. New Zealand Plant Protection. 66: 63-74.

Da Silva VCP, Nondillo A, Galzer ECW Garcia MS, Botton M 2017. Effect of host plants on the development, survivorship, and reproduction of Pseudococcus viburni (Hemiptera: Pseudococcidae). Florida Entomologist. 100(4): 718-724.

Damcevski KA, Annis PC, Waterford CJ 1998. Effect of grain on apparent respiration of adult stored-product Coleoptera in an airtight system: implications for fumigant testing. Journal of Stored Products Research 34(4): 331-339.

Dojchinov G, Haritos VS 2003. Mode of action of the rediscovered fumigant - ethyl formate. The BCPC International Congress: Crop Science and Technology, Volumes 1 and 2. Proceedings of an international congress held at the SECC, Glasgow, Scotland, UK, 10-12 November 2003. Pp. 851-856.

FDA 2017. GRAS Substances (SCOGS) Database. http://www.fda.gov/Food/Ingredients PackagingLabelling/GRAS/SCOGS/default. htm. Accessed 31 Oct 2017.

Förster TD, Hetz SK 2010. Spiracle activity in moth pupae-The role of oxygen and carbon dioxide revisited. Journal of Insect Physiology 56(5): 492-501.

Griffin MJ, Jamieson LE, Chhagan A, PageWeir NEM, Poulton J, Davis VA, Zulhendri F, Connolly PG 2013. The potential of ethyl formate + carbon dioxide to control a range of horticultural pests. New Zealand Plant Protection 66: 54-62.

Haritos VS, Damcevski KA, Dojchinov G 2006. Improved efficacy of ethyl formate against stored grain insects by combination with carbon dioxide in a 'dynamic' application. Pest Management Science 62(4): 325-333.

Heinrich E, Bradley T 2014. Temperaturedependent variation in gas exchange patterns and spiracular control in Rhodnius prolixus. Journal of Experimental Biology 217: 2752- 
2760.

Jamieson L, Chhagan A, Page-Weir N, Connolly P, DeSilva N, Phillips C 2009. Coolstorage for retaining market access for New Zealand kiwifruit. Postharvest Pacifica 2009, Australasian Postharvest and Managing Quality in Chains Conference. Pp. 41.

Jamieson LE, Page-Weir NEM, Chhagan A, Brash DW, Klementz D, Bycroft BL, Connolly PG, Waddell BC, Gilbertson R, Bollen F 2012. Phosphine fumigation to disinfest kiwifruit. New Zealand Plant Protection 65: 35-43.

Jeffery PB, Banks NH 1994. Firmnesstemperature coefficient of kiwifruit. New Zealand Journal of Crop and Horticultural Science 22: 97-101.

Liesivuori J, Savolainen H 1991. Methanol and Formic Acid Toxicity: Biochemical Mechanisms. Pharmacology \& Toxicology 69(3): 157-163.

Lighton JRB 1988. Discontinuous $\mathrm{CO}_{2}$ emission in a small insect, the formicine ant Camponotus vicinus. Journal of Experimental Biology 134: 363-376.

Ritenour MA, Crisosto CH, Garner DT, Cheng GW, Zoffoli JP 1999. Temperature, length of cold storage and maturity influence the ripening rate of ethylene-preconditioned kiwifruit. Postharvest Biology and Technology 15(2): 107-115.

Simpson T, Bikoba V, Tipping C, Mitcham E 2007. Ethyl formate as a postharvest fumigant for selected pests of table grapes. Journal of Economic Entomology 100(4): 1084-1090.

Thienel M, Canals M, Bozinovic F, Veloso C 2015. The effects of temperature on the gas exchange cycle in Agathemera crassa. Comparative Biochemistry and Physiology Part A 183: 126-130.

UNEP 2000. The Montreal Protocol on Substances that Deplete the Ozone Layer as either adjusted and/or amended in London 1990, Copenhagen 1992, Vienna 1995, Montreal 1997, Beijing 1999. United Nations Environment Program Ozone Secreariat, Nairobi. 54 pp.

Vincent L, Lindgren D 1972. Hydrogen phosphide and ethyl formate: Fumigation of insects infesting dates and other dried fruits. Journal of Economic Entomology 65(6): 1667-1669.

Woolf A, McDonald R, Rogers D, Olsson, S, Redpath S, O’Donoghue E, Cate L, Griffin M, Page-Weir N, Chhagan A, White A, Walker J, Jamieson L 2015. Advances in application of high pressure washing to enhance market access. Acta Horticulturae 1105: 385-390.

Woolf A, Page-Weir N, Oliver R, Hawthorne A, Chhagan A, Hartnett D, Feng R, Nangul A, McKenna C, Dobson S, Stannard K, Rowe C, Puketapu A, Mauchline A, Wood M, Jamieson L 2017. High pressure air for pest removal from kiwifruit. New Zealand Plant Protection 70: 315.

Xin N, Ren YL, Forrester RI, Ming X, Mahon D 2008. Toxicity of ethyl formate to adult Sitophilus oryzae (L.), Tribolium castaneum (Herbst) and Rhyzopertha dominica (F.). Journal of Stored Products Research 44(3): 241-246. 